\title{
Prediksi Aliran Kas Berdasarkan Laba Fungsional dan Aliran Kas Kelambanan: Komparasi antara US dan Indonesia
}

\author{
I Made Narsa \\ Fakultas Ekonomi Universitas Airlangga \\ Email: narsa_ua@yahoo.com
}

\begin{abstract}
ABSTRAK
Pengklasifikasian negara menjadi negara maju vs negara berkembang, pasar modal mapan vs pasar modal baru tumbuh, budaya individualistik vs kolektifistik; US vs. non-US; common law vs. civil law, dan lain sebagainya, telah mendorong banyak perhatian untuk melakukan riset dan membandingkan berbagai aspek dari negara-negara tersebut. Penelitian ini bertujuan untuk menguji kemampuan laba fungsional dan aliran kas kelambanan $\left(C F_{t-n}\right)$ dalam menjelaskan dan memprediksi aliran kasa masa depan, dan membandingkan kemampuan tersebut antara negara US dan Indonesia. Penelitian ini juga merupakan perluasan dari penelitian yang dilakukan oleh Narsa (2008) yang menguji kemampuan laba fungsional di Indonesia. Dengan menggunakan data panel perioda 2001-2008, penelitian ini menemukan bahwa laba kotor memiliki kemampuan prediksi paling kuat dalam menjelaskan dan memprediksi aliran kas masa depan dibandingkan dengan laba lainnya untuk konteks di Indonesia, tetapi untuk di US adalah laba bersih. Kemampuan laba fungsional dan aliran kas kelambanan ditemukan berbeda antara perusahaan-perusahaan di Indonesia dan US. Oleh karena itu, jika investor ingin memprediksi aliran kas masa depan, maka akan lebih akurat jika menggunakan komponen laba kotor untuk di Indonesia dan komponen laba bersih untuk di US.
\end{abstract}

Kata kunci: Aliran kas masa depan, aliran kas kelambanan, kemampuan menjelaskan, laba fungsional.

\begin{abstract}
Classification of countries by developed vs. developing countries; developed vs emerging capital market; individualistic vs. collectivistic culture; US vs. non-US countries, common law us. civil law, etc., have encouraged more research and compare other aspects of those countries. This research was conducted to test the ability of functional profit and lagged cash flow $\left(C F_{t-n}\right)$ in explaining and predicting future cash flow, and to compare this ability between US and Indonesian companies. This research is an extention of Narsa's research (2008) that was conducted for the Indonesian companies. Using the panel data for the 2001-2008 period, it documented that gross profit have the strongest explanatory power to predict future cash flow than other type of profit for Indonesia context, but on the other hand, it is the operating profit for the US context. The ability of functional profit and lagged cash flow to predict are different between US and Indonesian companies. Therefore, if investors wish to predict future cash flow, it would be more accurate to rely on gross profit component for Indonesia, and operating profit for the US.
\end{abstract}

Keywords: future cash flow, lagged cash flow, explanatory power, functional profit.

\section{PENDAHULUAN}

Dua jenis informasi akuntansi yang mengukur kinerja operasional perusahaan dan mendapat perhatian paling utama dari investor dan kreditor adalah laba rugi dan aliran kas. Ketika investor dihadapkan pada dua indikator kinerja tersebut, investor dan kreditor harus yakin bahwa indikator kinerja yang menjadi fokus perhatian mereka adalah indikator kinerja yang paling 
mampu menggambarkan kondisi ekonomi perusahaan serta prospek pertumbuhan di masa depan dengan lebih baik.

Penelitian empiris untuk menguji kandungan informasi laba sudah dimulai sejak tahun 1968, yang dipicu oleh hasil penelitian Ball dan Brown (1968) dan Beaver (1968). Ball \& Brown melakukan event study untuk menguji kandungan informasi dari accounting income numbers dengan meneliti 261 perusahaan selama 9 tahun (19571965). Beaver juga menguji kandungan informasi pengumuman laba tahunan, yang mengindikasikan bahwa laba akuntansi berhubungan dengan peristiwa yang dianggap investor memengaruhi harga saham sehingga investor menggunakan informasi tersebut untuk mengubah peramalan labanya dan menyesuaikan harga dengan tepat.

Sampai saat ini penelitian-penelitian mengenai laba terus berkembang baik mengenai ada tidaknya kandungan informasi (information content) maupun arah hubungan (direction) dengan harga saham. Mulai tahun 1980-an perhatian penelitian beralih pada besaran (magnitude) dari reaksi pasar yang diukur dengan earnings response coefficient (ERC). Penelitian awal tentang ERC dilakukan oleh (Bamber, 1986; Collins \& Kothari, 1989; Easton \& Harris, 1991; Easton \& Zmijewski, 1989; Kormendi \& Lipe, 1987; Richadson, 2003; Schipper \& Vincent, 2003)

Hubungan antara aliran kas dan laba akrual dengan abnormal return telah diteliti oleh Livnat dan Zarowin (1990) Pengujian dilakukan dengan analisis regresi berganda dan berhasil membuktikan bahwa komponen aliran kas mempunyai hubungan positif lebih kuat dengan abnormal return saham dibandingkan dengan aliran kas total atau laba akrual dengan abnormal return.

Tetapi hasil penelitian yang dilakukan Ali (1994) menunjukkan sebaliknya. Ali menguji kandungan informasi laba, modal kerja operasi, dan aliran kas dengan menggunakan regresi linear dan non linear. Hasil analisis berdasarkan model linear menunjukkan bahwa aliran kas relatif tidak memiliki kandungan informasi dibandingkan dengan variabel laba dan modal kerja operasi.

Salah satu tujuan pelaporan keuangan sebagaimana terdapat pada SFAC No. 1 (FASB, 1978: par. No. 37) adalah menyediakan informasi untuk membandu investor, kreditor dan pemakai lainnya dalam menaksir jumlah, waktu dan ketidakpastian aliran kas masa depan. Pertanyaannya adalah, informasi akuntansi yang mana yang paling baik digunakan untuk memprediksi aliran kas masa depan? Apakah laba rugi atau aliran kas itu sendiri?
Dalam menyusun laporan laba rugi, perusahaan publik dapat memilih salah satu dari dua metoda pengklasifikasian biaya, yaitu metoda sifat biaya dan metoda fungsional. Praktiknya untuk perusahaan publik di Indonesia dan di US menggunakan metoda fungsional. Jika suatu perusahaan menggunakan metoda fungsional dalam mengklasifikasikan beban, maka dalam laporan laba rugi akan tampak tiga jenis angka laba, yaitu laba kotor, laba operasi, dan di bawah laba operasi disajikan pos-pos di luar usaha dan pos-pos luar biasa, sehingga pada baris paling bawah (bottom line) terdapat laba bersih (IAI, 2002: paragraf 62). Dari tiga jenis laba fungsional tersebut, laba kotor relatif paling bebas dari diskresi manajemen sehingga 'dianggap' paling bersih dari manipulasi dan pos-pos akrual.

Sebagian besar penelitian-penelitian empiris yang ada sampai saat ini hanya fokus pada laba agregat atau disebut juga bottom line earnings, baik dalam rangka menguji kandungan informasi dengan melihat reaksi pasar maupun untuk tujuan prediksi laba masa depan dan aliran kas masa depan (Ball \& Brown, 1968; Beaver, 1968; Finger, 1994; Foster, 1977; Lipe, 1986; Ou, 1990; Strong \& Walker, 1993). Semua penelitian tersebut menggunakan laba agregat (earnings) sebagai variabel yang diteliti. Para peneliti tidak menggunakan pertimbangan bahwa angka laba akuntansi sebenarnya memiliki gradasi kandungan intervensi manajemen. Kalaupun pertimbangan itu ada hanya berhenti pada tingkat laba operasi, tidak sampai ke tingkat laba kotor. Sementara penelitian lainnya (Fairfield et al., 1996) memecah angka laba menjadi laba permanen, laba transitori, dan laba pengganggu, tetapi Kormendi memecah laba menjadi laba persistence dan laba non persistence (Kormendi \& Lipe, 1987).

Sementara itu, Narsa (2008) telah meneliti kemampuan laba fungsional dalam memprediksi perilaku aliran kas masa depan untuk kasus perusahaan-perusahaan di Indonesia. Pertanyaannya adalah apakah hasil penelitian tersebut sama atau berbeda jika dibandingkan dengan kondisi di negara-negara yang memiliki perbedaan dalam

berbagai aspek dengan Indonesia, seperti Amerika? Bedford mengingatkan bahwa makna laba akuntansi hanya bisa dimengerti dengan jalan memahami bagaimana angka laba tersebut bisa dihasilkan atau diukur. Ketiga angka laba tersebut memiliki makna semantik yang berbeda dan dengan perbedaan tersebut seharusnya juga memiliki efek pragmatik yang berbeda terhadap penggunanya (Bedford, 1971).

Oleh karena itu, penelitian ini bertujuan untuk menguji kemampuan tiga angka laba 
fungsional, yaitu laba kotor, laba operasi dan laba bersih serta aliran kas masa lalu (kelambanan) dalam menjelaskan perilaku aliran kas masa depan. Tujuan kedua adalah mengkomparasikan kemampuan tiga angka laba tersebut dan aliran kas masa lalu antar dua negara yang ada pada dua ekstrim dikotomik, yaitu US dan Indonesia, yang masing-masing mencerminkan negara maju dan berkembang, pasar modal maju dan berkembang, budaya individualistik dan kolektivistik, dan negara dengan sistem hukum common law dan civil law.

Dengan menggunakan data panel yang diambil dari www.jsx.co.id, ICMD dan OSIRIS (DataBase UGM), penelitian ini berhasil mendokumentasikan bahwa laba kotor memiliki kemampuan paling kuat dalam menjelaskan perilaku aliran kas masa depan untuk kasus di Indonesia atau hipótesis pertama didukung, konsisten dengan Narsa (2008). Tetapi, penelitian ini juga mendokumentasikan, bahwa untuk data US, laba operasi lebih kuat dibandingkan dengan laba kotor dan laba bersih. Ini beratri hipotesis pertama tidak didukung data empiris. Temuan ini sekaligus mendukung hipotesis kedua yang menyatakan terdapat perbedaan kemampuan laba fungsional dalam menjelaskan aliran kas masa depan antara kedua negara. Dengan demikian jika investor ingin memprediksi aliran kas masa depan lebih tepat menggunakan laba kotor untuk kasus di Indonesia dan laba operasi untuk di US.

Bagian berikut dari laporan hasil penelitian ini menjelaskan secara berturut-turut, yaitu bagian dua menjelaskan teori dan pengembangan hipótesis. Ada dua hipótesis yang diajukan untuk masing-masing negara. Bagian ketiga menjelaskan metoda penelitian mencakup data, dan variabel-variabel penelitian serta model empirik yang dikembangkan. Bagian keempat menjelaskan analisis dan hasil penelitian, dan bagian kelima berisi diskusi, simpulan dan saran.

\section{KAJIAN TEORI DAN PENGEMBANGAN HIPOTESIS}

Informasi yang terdapat dalam laporan laba rugi mencerminkan apa yang telah dilakukan oleh manajemen (stewardship) selama satu perioda. Para pemakai menilai apa yang telah dilakukan oleh manajemen, agar dapat mengambil keputusan ekonomi. Informasi kinerja perusahaan, terutama profitabilitas, diperlukan untuk menilai perubahan potensial sumberdaya ekonomi yang mungkin dapat dikendalikan di masa depan serta untuk memprediksi kapasitas perusahaan dalam menghasilkan aliran kas dari sumber daya yang ada (IAI 2002: par 14 dan 17).
Dalam laporan laba rugi perusahaan-perusahaan publik, khususnya untuk perusahaan dagang dan manufaktur, secara eksplisit ditunjukkan ada tiga jenis laba, yaitu laba kotor, laba operasi dan laba bersih. Penelitian-penelitian yang sudah dilakukan sebagian besar fokus pada laba operasi atau laba permanen atau laba persisten, dan laba bersih yang juga disebut laba agregat. Laba yang diperoleh dari kegiatan yang tidak berulang disebut laba transitori (Ali \& Zarowin, 1992; Beaver et al., 1979; Fairfield et al., 1996; Lipe, 1986; Ohlson \& Penman, 1992; Sloan, 1996).

Angka laba sebenarnya mengandung banyak sekali diskresi manajemen. Boleh jadi angka laba berubah tetapi tidak berdampak pada aliran kas. Sedangkan penelitian empiris membuktikan diskresi manajemen dalam pemilihan metoda akuntansi yang tidak berdampak pada aliran kas tidak direspon oleh pasar (Dopuch \& Pincus 1988; Fellingham 1988).

Secara semantik dan sintaktik laba kotor adalah selisih dari pendapatan perusahaan dikurangi dengan beban pokok penjualan. Beban pokok penjualan adalah semua biaya yang behubungan dengan pemerolehan barang dagangan baik melalui proses produksi maupun pembelian bagi perusahaan dagang. Laba operasi adalah selisih laba kotor dengan biaya-biaya operasi, yaitu biaya-biaya yang berhubungan dengan kegiatan operasi perusahaan. Laba bersih adalah angka yang menunjukkan selisih antara seluruh pendapatan-yang operatif maupun tidak—dan seluruh biaya—yang operatif maupun tidak.

Sampai sejauh ini yang paling populer adalah penggunaan laba operasi dan laba bersih sebagai variabel dalam penelitian pasar modal. Alasannya adalah laba operasi lebih mampu menggambarkan operasi perusahaan dibandingkan dengan laba bersih. Laba bersih dianggap masih dipengaruhi oleh hal-hal lain yang ada di luar kendali manajemen, misalnya peristiwa luar biasa yang meningkatkan laba atau menurunkan laba. Selain itu, laba operasi juga diasumsi memiliki hubungan langsung dengan proses penciptaan laba.

Namun Bhattacharya et al. (2003) mencoba membandingkan tingkat keinforma-tifan laba operasi dengan laba proforma. Hasil penelitian mereka menunjukkan bahwa laba pro forma lebih informatif dan lebih permanen sifatnya dibandingkan dengan laba operasi (Bhattacharya et al. 2003). Angka laba operasi bukan merupakan angka laba yang paling kuat menjelaskan reaksi pasar. Ini berarti, seharusnya, ada angka laba lain yang lebih kuat. 
Laba kotor sebenarnya lebih terkendali oleh manajer dan memiliki hubungan yang lebih erat dengan penciptaan pendapatan dibandingkan dengan laba operasi. Kos barang terjual juga relatif bebas dari pilihan metoda akuntansi. Jika pun ada, hanya pilihan antara FIFO dan LIFO yang di dalam penelitian dibuktikan tidak memengaruhi keputusan investor (Dopuch \& Pincus 1988; Fellingham 1988).

Masalah pembebanan biaya overhead pabrik sebenarnya tidak terlalu mengubah nilai akhir beban pokok penjualan. Penggunaan metoda perhitungan harga pokok produksi dengan pendekatan $\mathrm{ABC}$ dan just-in-time, misalnya, adalah bukti bahwa manajemen berusaha keras untuk mengendalikan beban pokok penjualan. Memang, beban pokok penjualan tidak bisa bebas sepenuhnya dari diskresi manajemen, tetatpi jenis laba lainnya jauh lebih 'parah'.

Tabel 1 mencerminkan gradasi intervensi managemen dalam menentukan besarnya angka laba, baik melalui pilihan metoda akuntansi maupun kebijakan manajemen, misalnya dalam bentuk penentuan cadangan kerugian piutang, umur ekonomi aktiva tetap, dan lain sebagainya.

Tabel 1. Perbandingan Tingkat Kebebasan Relatif terhadap Diskresi Manajemen

\begin{tabular}{|c|c|c|c|c|}
\hline Jenis Laba & \multicolumn{2}{|c|}{$\begin{array}{c}\text { Diskresi } \\
\text { Manajemen }\end{array}$} & $\begin{array}{c}\text { Non Related } \\
\text { Activity }\end{array}$ & $\begin{array}{c}\text { Kualitas } \\
\text { Laba }\end{array}$ \\
\hline Laba Kotor (LK) & COGS & & & \\
\hline Laba Operasi (LO) & COGS & Opr.Exp & & $\mathrm{LK}>\mathrm{LO}>\mathrm{LB}$ \\
\hline Laba Bersih (LB) & COGS & Opr.Exp & Other \& Extra & \\
\hline
\end{tabular}

Dari Tabel 1, tampak bahwa laba kotor dilaporkan dalam urutan pertama dalam laporan laba rugi, kemudian laba operasi dan terakhir laba bersih. Artinya, pertama perhitungan angka laba kotor akan menyertakan lebih sedikit komponen pendapatan dan biaya dibandingkan dengan penghitungan laba operasi, dan demikian pula dalam perhitungan komponen laba bersih. Kedua, komponen laba kotor akan terkontaminasi pilihan metoda dan diskresi manajemen paling sedikit dibandingkan dengan laba operasi dan laba bersih. Ketiga, laba kotor lebih sehat dibandingkan dengan laba operasi, dan laba operasi lebih sehat dibandingkan dengan laba bersih. Dengan demikian, dari logika ini, seharusnya angka laba kotor memiliki kemampuan menjelaskan perilaku aliran kas paling kuat dibandingkan dengan dua angka laba yang lainnya.

Berdasarkan kajian teoritis dan kerangka model pada Gambar 1, hipotesis dapat dirumuskan sebagai berikut:

H1: Angka laba kotor memiliki kemampuan lebih tinggi dibandingkan dengan angka laba operasi dan laba bersih dalam menjelaskan perilaku aliran kas, baik untuk kasus US maupun kasus Indonesia.
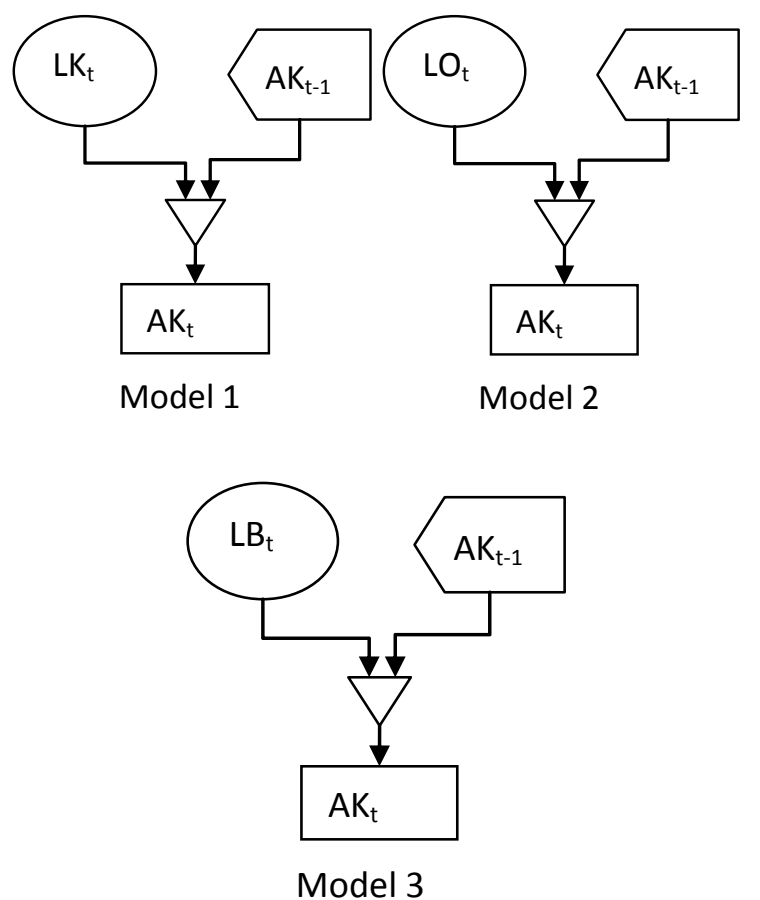

Gambar 1. Model Prediksi Aliran Kas berdasarkan Tiga Angka Laba dan Aliran Kas Kelambanan

Keterangan:

LK = Laba Kotor;

LO = Laba Operasi;

LB = Laba Bersih;

$\mathrm{AK}=$ Aliran Kas, dan

AKt. 1 = Aliran Kas Kelambanan (selanjutnya diberi label AKK)

Beberapa penelitian mencoba menghubungkan antara sistem hukum yang dianut suatu negara dengan proteksi hukum terhadap investor (La Porta et al 1998), dan menemukan bahwa negaranegara dengan sistem civil law memiliki sistem proteksi investor lebih lemah dibandingkan dengan negara dengan common law. Indonesia menganut civil law sedangkan US menganut common law. Leuz (2003) menemukan bahwa Negara dengan sistem proteksi hukum yang kuat terhadap investor, praktik earnings management lebih rendah. Hukum sipil (civil law) atau yang biasa dikenal dengan Romano-Germanic Legal System adalah sistem hukum yang berkembang di dataran Eropa. Titik tekan pada sistem hukum ini adalah, penggunaan aturan-aturan. hukum yang sifatnya tertulis. Sistem hukum ini berkembang di daratan Eropa sehingga dikenal juga dengan sistem Eropa Kontinental. Kemudian disebarkan negara-negara Eropa Daratan kepada daerahdaerah jajahannya, termasuk Indonesia oleh Belanda. Sedangkan Common-law membentuk 
bagian utama dari hukum banyak negara, terutama di negara-negara yang merupakan bekas koloni atau wilayah dari Britania. Dia terkenal karena terdapat hukum tidak tertulis (nonstatutory) yang luas mencerminkan sebuah konsensus penghakiman dengan sejarah berabadabad oleh para juris. Sebagai contoh di US yang mana dalam proses peradilannya menggunakan juri sebagai pengambil keputusan apakah seseorang dinyatakan guilty atau not-guilty.

Francis et al. (2001) juga menemukan bahwa Negara dengan sistem common law memiliki standar akuntansi yang lebih tranparan serta kebutuhan akan auditing yang lebih tinggi. Ini berarti, US dibandingkan dengan Indonesia memiliki standar akuntansi yang lebih tranparan, praktik earnings management dan tingkat kebutuhan auditing yang lebih rendah, sehingga tingkat intervensi manajemen terhadap pembentukan komponen laba fungsional relative lebih rendah. Dengan demikian, berdasarkan hasil-hasil penelitian tersebut dapat dirumuskan hipotesis kedua sebagai berikut:

$\mathrm{H}_{2}$ : Terdapat perbedaan kemampuan tiga angka laba dan aliran kas kelambanan dalam memprediksi aliran kas masa depan antara US dan Indonesia.

\section{METODE PENELITIAN}

Penelitian ini merupakan penelitian empirik dengan pendekatan kuantitatif. Data arsip yang digunakan adalah data panel, karena data akuntansi yang tersedia berupa data tahunan, sehingga sulit mendapatkan data runtun waktu yang panjang (misal 100 tahun) terutama untuk data Indonesia. Untuk perusahaan Indonesia, data panel yang dipergunakan dalam penelitian ini adalah 8 x 54, yaitu runtun waktu pendek yaitu hanya 8 tahun (2001-2008) dan data silang tempat sebanyak 54 perusahaan, sehingga secara keseluruhan jumlah observasi menjadi 432 observasi (tahun-perusahaan). Sumber data adalah laporan keuangan tahunan dari perusahaan publik di Bursa Efek Jakarta (www.jsx.co.id) dan Indonesian Capital Market Directory (ICMD). Untuk perusahaan US, data panel yang dipergunakan dalam penelitian ini adalah 8 x $60=480$ tahun perusahaan Sumber data adalah OSIRIS (Data Base UGM). Pembatasan jumlah data panel US ini semata-mata untuk menyeimbangkan dengan data panel perusahaan publik di Indonesia.

Penggunaan data panel menyebabkan jumlah observasi meningkat (432 firm-year Indonesia, dan 480 firm-year US). Meningkatnya jumlah observasi dapat meningkatkan derajat kebebasan dan mengurangi kolinieritas antar variabel indepen- den, sehingga dapat memperbaiki estimasi ekonometri.

Karena data runtun waktu pendek, yaitu hanya delapan tahun (2001-2008), maka tidak diperlukan berbagai macam pengujian asumsi klasik seperti halnya dalam data runtun waktu panjang. Dalam hal ini diasumsikan nilai variabelvariabelnya adalah stabil dan statisioner. Verbeek (2004) mengatakan keuntungan regresi dengan data panel dibandingkan data runtun waktu atau data lintas sektoral adalah kemampuannya dalam mengidentifikasi parameter-parameter regresi secara pasti dengan tanpa membutuhkan asumsi restriksi (Verbeek 2004 : 342).

\section{Variabel-variabel Penelitian}

Laba fungsional, artinya bahwa setiap angka laba diperoleh setelah dilakukan pengurangan dengan biaya pada fungsi-fungsi tertentu. Laba Kotor (LK) adalah pendapatan dikurangi dengan biaya yang terjadi pada fungsi produksi (fungsi pembelian untuk perusahaan dagang), yaitu berupa kos barang terjual. Laba Operasi (LO) adalah laba kotor dikurangi biaya yang terjadi pada fungsi-fungsi operasi perusahaan meliputi biaya fungsi pemasaran, biaya fungsi administrasi dan umum. Laba Bersih (LB) adalah laba operasi dikurangi dengan pos-pos di luar fungsi utama perusahaan, yaitu pos-pos transitori dan pos-pos luar biasa; Aliran Kas Kelambanan (AKK) adalah angka aliran kas tahun sebelumnya. Sedangkan variabel dependen yang ingin diprediksi adalah Aliran Kas (AK). Nilai aliran kas yang dipergunakan dalam penelitian ini adalah aliran kas operasi

\section{Model Empiris}

Mengacu pada Gambar 1 di atas, maka model empirisnya adalah: 1)

$$
\mathrm{AK}_{\mathrm{t}}=\mathrm{a}_{0}+\mathrm{ab}_{1} \mathrm{LK}_{\mathrm{t}}+\mathrm{a}_{3} \mathrm{AK}_{\mathrm{t}-1}+\varepsilon \quad \text { (Model }
$$

2)

$$
\mathrm{AK}_{\mathrm{t}}=\mathrm{b}_{0}+\mathrm{b}_{2} \mathrm{LO}_{\mathrm{t}}+\mathrm{b}_{3} \mathrm{AK}_{\mathrm{t}-1}+\varepsilon \quad \text { (Model }
$$

$\mathrm{AK}_{\mathrm{t}}=\mathrm{c}_{0}+\mathrm{c} 3 \mathrm{LB}_{\mathrm{t}}+\mathrm{c}_{3} \mathrm{AK}_{\mathrm{t}-1}+\varepsilon($ Model 3$)$

Keterangan: AK adalah aliran kas; $\mathrm{AK}_{\mathrm{t}-1}$ adalah aliran kas kelambanan; a0, bo, co adalah intersep dari nilai AK; $a_{1,2}, b_{1,2}, c_{1,2}$ adalah slope dari garis regresi; LK adalah laba kotor; LO adalah laba operasi; LB adalah laba bersih, dan $\varepsilon$ adalah error term. 


\section{Kriteria Pemilihan Model Terbaik}

Pemilihan model empiris merupakan salah satu langkah penting, di samping pembentukan model teoritik dan model yang dapat ditaksir, estimasi, pengujian hipotesis, peramalan dan analisis mengenai implikasi kebijakan dari model tersebut (Insukindro, 1992). Suatu model dapat dikatagorikan baik, jika memenuhi beberapa syarat, yaitu: parsimony; data admissibility; data coherency; constant parameter; theoretical consistency; dan encompassing (Gujarati 2003:507; Insukindro 1999) Oleh karena itu, untuk menentukan model terbaik dipergunakan beberapa kriteria, yaitu: Pertama $R^{2}$, ukuran ini dipergunakan karena $R^{2}$ mengukur proporsi atau persentase dari variansi variabel $A K$ mampu dijelaskan oleh variansi variabel LK dan AKK (Model 1) atau LO dan AKK (Model 2), atau LB dan AKK (Model 3). Kedua, kriteria lain yang dipergunakan adalah Akaike info criterion (AIC), dan Schwarz criterion. Model terbaik adalah yang memiliki $\mathrm{R}^{2}$ terbesar, dan AIC dan Schwarz paling kecil. Untuk membandingkan model mana yang lebih baik antara kasus di Indonesia dan di US, maka dilakukan perbandingan secara visual untuk masing-masing model yang bersesuaian.

\section{HASIL PENELITIAN}

Pada Tabel 2 disajikan statistik deskriptif untuk empat variabel yang diteliti. Jumlah observasi sebanyak 432 tahun perusahaan untuk data Indonesia (Panel A) dan 480 tahun perusahaan untuk data US (Panel B). Dari seluruh observasi tersebut tampak bahwa variansi data sangat luas untuk semua variabel. Deskripsi ini mencerminkan bahwa aliran kas bisa negatif pada satu perioda dan bisa positif pada perioda lainnya. Demikian pula mengenai angka laba, dimana suatu perusahaan bisa mengalami kerugian pada satu perioda dan mengalami laba pada perioda lainnya.

Dengan membandingkan mean dan median pada kedua panel data tampak bahwa semua variabel memiliki mean yang lebih besar dibandingkan dengan median, artinya semua variabel condong ke kanan (positif). Ini berarti estimasi yang terbesar dari semua variabel adalah ratarata dibandingkan dengan median. Data yang memiliki sebaran paling tinggi adalah laba kotor. Hal ini bisa dilihat dari besarnya nilai deviasi standar, data lain juga memiliki sebaran yang rata-rata tinggi.

\section{Hasil Estimasi Model 1, 2, dan 3}

Oleh karena data panel menggunakan runtut waktu pendek, maka tidak diperlukan pengujian terhadap asumsi klasik sebagaimana dalam data runtut waktu panjang (Verbeek, 2004). Secara berturut-turut hasil estimasi masing-masing model disajikan pada Tabel 3.

Tabel 2: Statistik Deskriptif

PANEL A: Data Indonesia

\begin{tabular}{|c|c|c|c|c|c|}
\hline Statistik & AK & LK & $\mathrm{LO}$ & LB & AKK \\
\hline Mean & 181978.9 & 496720.5 & 265952.9 & 154776.6 & 182366.5 \\
\hline Median & 34062.82 & 79843.00 & 33461.00 & 13588.00 & 34690.54 \\
\hline Maximum & 6939709. & 13722876 & 6413974. & 8205759. & 6939709. \\
\hline Minimum & -843544.8 & -110800.0 & -210728.0 & -6399867. & -843544.8 \\
\hline Std. Dev. & 601278.5 & 1404088. & 766404.5 & 989557.8 & 601227.3 \\
\hline Skewness & 5.771956 & 4.740335 & 3.986812 & 3.156928 & 5.771540 \\
\hline Kurtosis & 48.79632 & 31.33544 & 20.90637 & 35.28409 & 48.79803 \\
\hline Observations & 431 & 431 & 431 & 431 & 431 \\
\hline
\end{tabular}

PANEL B: Data US

\begin{tabular}{llllll}
\hline Statistik & AK & LK & LO & LB & AKK \\
\hline Mean & 1061.193 & 2915.328 & 799.7435 & 507.0331 & 1071.884 \\
Median & 478.7670 & 1705.923 & 388.4610 & 203.8750 & 480.8550 \\
Maximum & 14851.00 & 23049.00 & 11882.00 & 10535.00 & 14851.00 \\
Minimum & -5611.000 & -5.444000 & -4222.000 & -3937.000 & -5611.000 \\
Std. Dev. & 1902.360 & 3644.658 & 1492.521 & 1198.434 & 1911.468 \\
Skewness & 3.537885 & 2.638274 & 3.401537 & 3.515630 & 3.493012 \\
Kurtosis & 20.98149 & 10.89613 & 20.87444 & 23.98457 & 20.55420 \\
Observations & 479 & 479 & 479 & 479 & 479 \\
\hline
\end{tabular}

Sumber: Data diolah

Keterangan: AK adalah aliran kas; LK adalah laba kotor; LO adalah laba operasi; LB adalah laba bersih, dan AKK adalah Aliran Kas Kelambanan. 
Tabel 3. Kriteria Seleksi Model Terbaik: Variabel Bebas: Aliran Kas

\begin{tabular}{|c|c|c|c|c|c|c|}
\hline \multirow{2}{*}{$\begin{array}{c}\text { Variabel } \\
\text { Bebas }\end{array}$} & \multicolumn{2}{|c|}{ Model 1} & \multicolumn{2}{|c|}{ Model 2} & \multicolumn{2}{|c|}{ Model 3} \\
\hline & Indo & US & Indo & US & Indo & US \\
\hline Intercept & $\begin{array}{c}26306,40 \\
(1,23)\end{array}$ & $\begin{array}{l}-190,8275 \\
(-3,74)^{* * *}\end{array}$ & $\begin{array}{c}34080,90 \\
(1,56) \\
\end{array}$ & $\begin{array}{l}37,37762 \\
(0,83)^{* * * *}\end{array}$ & $\begin{array}{c}90295,12 \\
(3,75)^{*}\end{array}$ & $\begin{array}{c}137,561 \\
(2,99)^{* * * *}\end{array}$ \\
\hline LK & $\begin{array}{c}0,289 \\
(14,90)^{* * * *}\end{array}$ & $\begin{array}{c}0,281 \\
(16,34)^{* * * *}\end{array}$ & & & & \\
\hline $\mathrm{LO}$ & & & $\begin{array}{c}0,536 \\
(13,82)^{* * *}\end{array}$ & $\begin{array}{c}0,620 \\
(17,81)^{* * * *}\end{array}$ & & \\
\hline $\mathrm{LB}$ & & & & & $\begin{array}{c}0,231 \\
(8,21)^{* * * *}\end{array}$ & $\begin{array}{c}0,710 \\
(16,06)^{* * *}\end{array}$ \\
\hline$\overline{\mathrm{AKK}}$ & $\begin{array}{l}0,065 \\
(1,43) \\
\end{array}$ & $\begin{array}{c}0,404 \\
(12,33)^{* * *}\end{array}$ & $\begin{array}{c}0,029144 \\
(0,58)\end{array}$ & $\begin{array}{c}0,492292 \\
(18,12)^{* * *}\end{array}$ & $\begin{array}{c}0,306 \\
(6,58)^{* * * *}\end{array}$ & $\begin{array}{c}0,525 \\
(18,95)^{* * * *}\end{array}$ \\
\hline $\mathrm{N}$ & 431 & 479 & 431 & 479 & 431 & 479 \\
\hline R2 & 0,521 & 0,792 & 0,496 & 0,805 & 0,371 & 0,789 \\
\hline Adj. R2 & $0,518^{a)}$ & 0,791 & 0,494 & $0,804^{\text {a) }}$ & 0,368 & 0,788 \\
\hline $\mathrm{F}$ & 232,468 & 907,325 & 211,038 & 984,795 & 126,224 & 892,994 \\
\hline Kriteria & & & & & & \\
\hline $\mathrm{AIC}$ & 28,727 a) & 16,378 & 28,776 & $16,313^{a)}$ & 28,999 & 16,391 \\
\hline Schwarz & $28,756^{\text {a) }}$ & 16,404 & 28,805 & $16,339^{\text {a) }}$ & 29,027 & 16,417 \\
\hline
\end{tabular}

Sumber: Data diolah

Keterangan: * = Signifikan pada level 10\% ; ** sig pada level 5\%; *** sig pada level 1\%.

a) menunjukkan memenuhi kriteria paling baik.

Dari Tabel 3, tampak bahwa hasil estimasi Model 1 (Indo) dengan menggunakan LK dan AKK sebagai prediktor, ternyata LK signifikan secara statistik dalam mengestimasi AK pada level 1\%. Standar kesalahan sangat kecil yaitu sebesar 0.019. Tetapi variabel AKK tidak signifikan secara statistik. Secara keseluruhan Model 1 (Indo) memiliki googness of fit yang tinggi dengan nilai $\mathrm{F}$ $=232.4686(p=0.0000)$. Di samping itu variansi perubahan nilai aliran kas dapat dijelaskan oleh variansi variabel LK dan AKK sebesar 51.84\%.

Berdasarkan hasil estimasi Model 1 (US), ternyata LK juga sangat signifikan secara statistik dalam mengestimasi AK pada level 1\%, dengan standar kesalahan sebesar 0.017187. Demikian juga variabel AKK signifikan secara statistik pada level 1\% dengan standar kesalahan 0.032772 . Secara keseluruhan Model 1 (US) memiliki googness of fit yang sangat tinggi dengan nilai $\mathrm{F}=$ $907.3255(p=0.0000)$. Di samping itu variansi perubahan nilai aliran kas dapat dijelaskan oleh variansi variabel LK dan AKK sebesar 79.22\%.

Hasil estimasi Model 2 (Indo) dengan variabel prediktor LO dan AKK menunjukkan bahwa LO signifikan secara statistik pada level $1 \%$ dalam memprediksi AK. Namun AKK pengaruhnya tidak signifikan secara statistik. Model 2 (Indo) memiliki goodness of fit yang tinggi dengan nilai $\mathrm{F}$ $=211.0385$ dan $p$-value $=0.000$. Secara keseluruhan variabel LO dan AKK mampu menjelaskan variansi aliran kas sebesar sekitar $49.42 \%$, selebihnya dijelaskan oleh variabel lain yang tidak masuk dalam model.
Sementara hasil estimasi Model 2 (US) menunjukkan baik variabel LO maupun AKK sama-sama memiliki pengaruh yang signifikan dalam memprediksi aliran kas masa depan pada level 1\%. Model ini memiliki goodness of fit yang sangat tinggi dengan nilai $\mathrm{F}=984.7951(p=0.000)$. Secara keseluruhan variabel LO dan AKK mampu menjelaskan variansi aliran kas sebesar sekitar $80.54 \%$, selebihnya dijelaskan oleh variabel lain yang tidak masuk dalam model.

Hasil estimasi Model 3 (Indo) dengan variabel prediktor LB dan AKKkeduanya signifikan secara statistik dalam memprediksi AK pada level $1 \%$. Model ini juga memiliki goodness of fit yang sangat bagus dengan nilai $\mathrm{F}=126.2247(p=0.0000)$. Variansi perubahan aliran kas mampu dijelaskan oleh variansi $\mathrm{LB}$ dan AKK sekitar 36.81\%, selebihnya dijelaskan oleh variabel lain yang tidak masuk dalam model.

Sementara pada Model 3 (US) tampak bahwa variabel LO dan AKK sama-sama memiliki pengaruh yang signifikan dalam memprediksi AK masa depan pada level 1\%. Tingkat goodness of fit juga sangat tinggi dengan nilai uji $\mathrm{F}=892.9942(p$ $=0.000$ ). Secara keseluruhan variabel LO dan AKK mampu menjelaskan variansi aliran kas sebesar sekitar 78.95\%, selebihnya dijelaskan oleh variabel lain yang tidak masuk dalam model.

Dari semua hasil estimasi sebagaimana disajikan pada Tabel 3, tampak bahwa angka laba ternyata memiliki kemampuan yang baik untuk menjelaskan aliran kas. Goodness of fit ketiga model tersebut yang dilihat dari nilai uji $\mathrm{F}$ sangat 
tinggi dan signifikan pada level di bawah satu persen. Namun untuk memutuskan mana model yang paling baik atau paling kuat dalam menjelaskan aliran kas, juga perlu menggunakan kriteria-kriteria seleksi yang lain, yang dibahas berikut ini.

\section{Seleksi Model}

Seperti sudah dijelaskan pada bagian metoda penelitian, bahwa untuk memilih model terbaik digunakan beberapa kriteria seleksi seperti $R^{2}$, AIC, dan Schwarz criterion Tabel 3 berikut menyajikan secara lengkap ringkasan dari hasil pengujian dan estimasi terhadap ketiga model di kedua negara.

Dari Tabel 3, tampak bahwa untuk data Indonesia Model 1 memiliki $R^{2}$ dan Adjusted $R^{2}$ yang paling tinggi, juga goodness of fit $(F)$ yang paling baik. Nilai AIC dan Schwarz yang semakin kecil menunjukkan model semakin baik. Oleh karena itu, berdasarkan kriteria AIC dan Schwarz, model yang terbaik adalah Model 1. Ini berarti hipotesis yang diajukan bahwa Angka laba kotor memiliki kemampuan lebih tinggi dibandingkan dengan angka laba operasi dan laba bersih dalam menjelaskan perilaku aliran kas untuk kasus di Indonesia didukung data empiris. Namun, variabel aliran kas kelambanan tidak signifikan untuk ketiga model.

Selanjutnya, jika dilihat untuk data US, semua variabel $\mathrm{LK}, \mathrm{LO}, \mathrm{LB}$, dan AKK signifikan pada ketiga model, tetapi model yang paling baik adalah Model 2, artinya laba operasi dan aliran kas kelambanan memiliki kemampuan yang paling baik dalam menjelaskan perilaku aliran kas masa depan. Jika dihubungkan dengan penelitian terdahulu yang telah menguji laba operasi dan laba agregat hasilnya konsisten, dimana laba operasi memiliki daya prediksi yang lebih kuat dan direaksi oleh pasar lebih kuat dibandingkan dengan laba agregat (Ball \& Brown, 1968; Beaver, 1968; Brown \& Sivakumar, 2001; Butar-butar, 2004; Febriyanti, 2005; Finger, 1994; Foster, 1977; Lipe, 1986; Ou, 1990; Strong \& Walker, 1993; Swaminathan \& Weintrop, 1991). Penelitian ini juga mendokumentasikan, khususnya untuk data US, bahwa laba operasi lebih kuat dibandingkan dengan laba kotor dan laba bersih. Ini beratri hipotesis pertama tidak didukung data empiris. Temuan ini sekaligus mendukung hipotesis kedua yang menyatakan terdapat perbedaan kemampuan laba fungsional dalam menjelaskan aliran kas masa depan antara kedua negara. Perbedaan ini dijelaskan pada bagian diskusi berikut ini.

\section{ANALISA DAN PEMBAHASAN}

Berdasarkan hasil pengujian hipotesis, untuk kasus Indonesia, laba kotor memiliki kemampuan menjelaskan aliran kas paling kuat diantara dua jenis angka laba lainnya. Apa yang diharapkan oleh investor sebenarnya aliran kas yang baik di masa depan, sehingga perusahaan berkemampuan untuk membayarkan dividen. Bahkan SFAC menegaskan bahwa tujuan penyajian laporan keuangan adalah untuk membantu pemakai dalam menaksir aliran kas masa datang.

Seperti diuraikan pada bagian pendahuluan, apa dasar yang paling baik yang dapat dipergunakan untuk memprediksi aliran kas masa depan? Penelitian ini menemukan laba kotor memiliki kemampuan yang paling baik dalam menjelaskan perilaku aliran kas, yang berarti laba kotor memiliki kemampuan prediksi yang tinggi, khususnya untuk data Indonesia.

Hasil ini hanya dapat dipahami jika kita memperhatikan secara hati-hati proses penyusunan laporan laba rugi. Dalam proses penyusunan laporan keuangan, terutama laporan laba rugi, banyak ditemukan faktor-faktor yang memungkinkan sebuah angka laba angregat dan laba bersih mengandung manipulasi.

Worthy (1985:651) mengatakan "life is not smooth" demikian Ford S Worthy seorang auditor dari KAP besar di US mengemukakan kembali tentang faham kebenaran. Tidak satupun dalam kinerja tahun ke tahun (year-to-year performance) suatu perusahaan yang membebaskan eksekutifnya dari usaha 'menggoyang' garis yang memetakan profit mereka. Ada tiga jalan yang memungkinkan manajemen mengelola earnings, yaitu 1) karena mereka memiliki peluang yaitu berupa power yang dimiliki, sehingga bisa masuk dalam membuat aturan akuntansi; 2) feksibilitas dalam memilih cara menghitung earnings (karena banyak cara menghitung fakta yang sama), dan 3) estimasi yang subjektif. Cara paling umum yang dipakai oleh manajemen adalah pemilihan metoda akuntansi, menentukan estimasi secara subjektif, dan menggeser pendapatan maupun biaya ke perioda berikutnya. Caranya adalah dengan manipulasi aktivitas riil (Roychowdhury 2006), dan pemindahan klasifikasi (McVay 2006)

Laba kotor dilaporkan dalam urutan pertama dalam laporan laba rugi, kemudian laba operasi dan terakhir laba bersih. Artinya, 1) penghitungan angka laba kotor akan menyertakan lebih sedikit komponen pendapatan dan biaya dibandingkan dengan penghitungan laba operasi, dan selanjutnya penghitungan komponen laba bersih. 
2) komponen laba kotor akan terkontaminasi pilihan metoda dan diskresi manajemen paling sedikit dibandingkan dengan laba operasi dan laba bersih. 3) laba kotor lebih sehat dibandingkan dengan laba operasi, dan laba operasi lebih sehat dibandingkan dengan laba bersih.

Dikaitkan dengan pernyataan Scott (2003) bahwa laba tidak tumbuh dengan tingkat pertumbuhan yang permanen dan bahwa kualitas laba yang rendah dipengaruhi oleh pilihan metoda akuntansi, maka semakin rinci penghitungan suatu angka laba akan semakin banyak pilihan metoda akuntansi, semakin banyak diskresi manajemen, sehingga semakin rendah kualitas laba. Inilah yang menyebabkan mengapa angka laba kotor lebih sehat dan paling kuat menjelaskan perilaku aliran kas. Penelitian yang dilakukan oleh Swaminathan dan Weintrop (1991) tentang kandungan informasi laba, pendapatan, dan biayabiaya, menemukan bahwa pendapatan dan biaya memiliki kandungan informasi yang inkremental terhadap laba bersih.

Perbedaan kemampuan angka laba antara US dan Indonesia-untuk data US model yang paling baik adalah Model 2, sedangkan untuk data Indonesia adalah Model 1-mencerminkan adanya perbedaan tingkat manipulasi laba antara US dan Indonesia. La Porta (1997) menemukan bahwa negara-negara yang menganut civil law memiliki perlindungan hukum investor yang lebih lemah dibandingkan dengan negara-negara yang menganut common law. Lebih lanjut, negara dengan sistem perlindungan investor yang lebih lemah ditemukan adanya praktik earnings management yang lebih tinggi (Francis et al., 2001; Francis \& Wang, 2006; Francis et al., 2002).

Indonesia adalah negara yang menganut civil law, sedangkan US menganut sistem common law. Jika merujuk ke hasil penelitian-penelitian sebelumnya yang mengkontraskan antara negaranegara common law dan civil law, maka patut dicurigai bahwa laporan laba rugi antara US dan Indonesia mengandung tingkat earnings management yang berbeda. Indonesia tentunya memiliki tingkat earnings management yang lebih tinggi dibandingkan dengan US. Konsekuensinya, adalah kualitas laba operasi Indoneasia lebih buruk dibandingkan dengan laba operasi US. Hal ini menjelaskan mengapa Model 1 lebih baik untuk kasus Indonesia, sementara untuk kasus US model yang lebih baik adalah Model 2 .

Hasil penelitian lain yang mendukung kekuatan laba operasi adalah penelitian yang dilakukan oleh Brown dan Sivakumar (2001). Mereka membandingkan kualitas tiga angka laba kuartalan, yaitu laba operasi pro forma, EPS dari laba operasi, dan EPS dari laba sebelum pos-pos luar biasa dan operasi yang dihentikan, dan menemukan bahwa laba operasi pro-forma memiliki kualitas yang lebih baik dibandingkan dengan EPS dari operasi atau EPS dari laba sebelum pos-pos luar biasa dan operasi yang dihentikan. Karena penelitian-penelitian tersebut tidak meneliti sampai pada level laba paling awal yaitu laba kotor, maka sebenarnya temuan mereka konsisten dengan premis di atas, bahwa laba kotor lebih sehat dari laba operasi dan laba operasi lebih sehat dari laba bersih.

\section{KESIMPULAN}

Tujuan penelitian ini adalah untuk menguji kemampuan laba akuntansi yaitu laba kotor, laba operasi, dan laba bersih, serta aliran kas kelambanan dalam menjelaskan perilaku aliran kas. Ketika model yang diajukan diuji dengan data dari dua negara yang berada pada dua titik ekstrim, ternyata hasilnya sesuai dengan yang dihipotesiskan Untuk kasus Indonesia, hasil penelitian ini dapat menjelaskan mengapa laba kotor lebih direaksi oleh pasar dibandingkan dengan angka laba lainnya. Sementara untuk kasus US angka laba operasi yang lebih memiliki explanatory power.

Perlu diingat bahwa, besaran angka laba kotor maupun laba operasi bukanlah harapan bagi investor, karena investor lebih berharap pada potensi aliran kas masa depan sehingga perusahaan berkemampuan membayar deviden. Jika ada indikasi suatu perusahaan memiliki kemampuan yang tinggi untuk membayar deviden, maka saham perusahaan tersebut menjadi menarik, sehingga harga saham akan terdorong naik. Bagaimana menaksir aliran kas. Hasil penelitian ini telah memberikan bukti empiris tentang kemampuan laba kotor dalam memprediksi aliran kas untuk Indonesia, dan laba operasi untuk US. Hubungan tidak langsung inilah yang secara logik menyebabkan adanya reaksi terhadap angka laba kotor dan laba operasi.

Sebenarnya angka laba kotor lebih operatif dibandingkan dengan angka laba lainnya. Lebih dari 60\% kegiatan pokok perusahaan tercurah untuk memperoduksi barang atau pengadaan barang. Besarnya kegiatan pokok ini diukur dengan biaya dan tercermin pada angka beban pokok penjualan. Dengan demikian laba kotor akan lebih tepat digunakan sebagai pengukur kinerja. Di samping itu biaya produksi mengandung unsur diskresi manajemen jauh lebih sedikit dibandingkan dengan beban operasional, dan pospos transitori. 
Harus diakui bahwa sejak krisis ekonomi tahun 1998 sampai sekarang keadaan perekonomian belum stabil. Karakteristik data keuangan yang dipakai dalam penelitian ini adalah cerminan dari ketidakstabilan tersebut. Pada Tabel 2 tampak bahwa batas minimum dan maksimum data sangat luas dengan deviasi standar yang sangat tinggi. Batas minimum semua variabel negatif dan ada pada tingkat kerugian yang cukup tinggi. Tampaknya, pengujian model yang sama untuk kasus negara yang perekonomiannya lebih maju dan stabil telah memberikan insight ketika kondisi perusahaan yang tumbuh normal. Menggunakan data laporan keuangan dari pasar modal di luar negeri (misalnya Malaysia, Singapura, Hongkong, atau Jepang) mungkin ide yang bagus untuk mereplikasi penelitian ini. Dilihat dari sudut pandang teori keputusan maupun teori earnings management, hasil penelitian ini dan temuan penelitian terdahulu akan membawa implikasi pada sumber dan cara pencarian informasi dalam rangka menaksir aliran kas masa depan. Implikasi lainnya adalah terbukanya perspektif baru dalam penelitian pasar modal dengan adanya tambahan satu variabel baru yang selama ini terabaikan.

\section{DAFTAR PUSTAKA}

Ali, A. 1994. "The Incremental Information Content of Earnings, Working Capital from Operation and Cash Flows". Journal of Accounting Research, Vol 32, No 1: pp. 61 67.

Ali, A., \& Zarowin, P. 1992. "Permanent Versus Transitory Components of Annual Earnings and Estimation Error in Earnings Response Coefficients". Journal of Accounting and Economics Vol. 15: pp. 249 - 264.

Ball, R., \& Brown, P. 1968. "An Empirical Evaluation of Accounting Income Numbers" Journal of Accounting Research, Vol. 6, No. 2: pp. 158 - 178.

Bamber, L. S. 1986. "The Information Content of Annual Earnings Releases: A Trading Volume Approach" Journal of Accounting Research, Vol. 24, No. 1 pp. 40 - 56.

Beaver, W. H. 1968. "The Information Content of Annual Earnings Announcements. Empirical Research in Accounting: Selected Studies" Journal of Accounting Research, Vol. 4 (Supplement) pp. 67 - 92.

Beaver, W. H., Clarke, R., \& Wright, W. R. 1979. "The Association Between Unsystematic Security Returns and Magnitude of Ear- nings Forecast Errors". Journal of Accounting Research, Vol. 17, No. 2: pp. 316 - 340.

Bedford, N. M. 1971. Income Concept Complex: Expansion Or Decline, In Asset Valuation And Income Determination. Editor Robert. R. Sterling \& Lawrence Kans, Scholarbook: pp. 135 - 144.

Bhattacharya, N., Black, E. L., Christensen, T. E., \& Larson, C. R. 2003. "Assessing The Relative Informativeness And Permanence of Pro Forma Earnings and GAAP Operating Earnings", Journal of Accounting and Economics, Vol. 36: pp. 1-3.

Brown, L. D., \& Sivakumar, K. 2001. "Comparing The Quality Of Three Earnings Measures", http: / / www.ssrn.com /abstract $=272180$.

Butar-butar, S. 2004. "Predictive Content of Earnings Classification”, Makalah (tidak dipublikasikan), Simposium Nasional Akuntansi VII, Denpasar.

Collins, D. W., \& Kothari, S. P. 1989. "An analysis of Intertemporal and Cross-sectional Determinants of Earnings Response Coefficients", Journal of Accounting and Economics, Vol. 11: pp. 143 - 181.

Dopuch, N., \& Pincus, M. 1988. "Evidence On The Choice Of Inventory Accounting Methods: LIFO Versus FIFO”, Journal of Accounting Research, Vol. 26, No. 1: pp. 28 - 59.

Easton, P. D., \& Harris, T. S. 1991. "Earnings as An Explanatory Variable for Returns", Journal of Accounting Research, Vol. 29: pp. 19 - 36.

Easton, P. D., \& Zmijewski, M. 1989. "CrossSectional Variation In The Stock Market Response To Accounting Earnings Announcements", Journal of Accounting and Economics, Vol. 11: pp. 117 - 141.

Fairfield, P. M., Sweeney, R. J., \& Yohn, T. L. 1996. "Accounting Classification and the Predictive Content of Earnings" The Accounting Review, Vol. 71, No. 3: pp. 337 355

FASB. 1978. Objective of Financial Reporting by Business Enterprises. SFAC, No. 1.

Febriyanti, G. A. 2005. "Perbandingan Keakuratan Model Laba Permanen, Transitori, dan Agregat dalam Memprediksi Laba Masa Depan”. Makalah (tidak dipublikasikan), Simposium Nasional Akuntansi VIII, Solo.

Fellingham, J. 1988. "Disccusion of The LIFO/ FIFO Choise: An Asymetric Information Approach". Journal of Accounting Research, Vol. 26 (Supplement): pp. 59-76. 
Finger, C. A. 1994. "The Ability of Earnings to Predict Future Earnings and Cash Flow", Journal of Accounting Research, Vol. 32, No. 2: pp. 210-223.

Foster, G. 1977. "Quarterly Accounting Data: Time-Series Properties and Predictive Ability Results". The Accounting Review, Vol. LII, No. 1 (Jan): pp. 1-21.

Francis, J. R., Khurana, I. K., \& Pereira, R. 2001. "Investor Protection Laws, Accounting and Auditing Around the World", Working Paper: University of Missouri-Columbia.

Francis, J. R., \& Wang, D. 2006. “The Joint Effect of Investor Protection and Big 4 Audits on Earnings Quality Around the World", Working Paper: University of MissouriColumbia dan University of NebraskaLincoln.

Francis, J. R., Wang, D., \& Nikitkov, A. 2002. "The Effect of Legal Environment on Big Five Auditor Conservatism Around the World. Working Paper", University of MissouriColumbia.

Gujarati, D. N. 2003. Basic Econometrics, Fourth edition, Singapore: McGraw-Hill.

IAI. 2002. Pernyataan Standar Akuntansi Keuangan Indonesia No.1. Jakarta: Salemba Empat.

Insukindro. 1992. "Dynamic Specification of Demand for Money: A Survey of Recent Development", Jurnal Ekonomi Indonesia, Vol. 1, No. 1: hal. 9-23.

Insukindro. 1999. "Pembentukan Model dalam Penelitian Ekonomi", Jurnal Ekonomi dan Bisnis Endonesia, Tahun VII, No. 1: hal. 18.

Kormendi, R., \& Lipe, R. 1987. "Earnings Innovations, Earnings Persistence, and Stock Returns", Journal of Business, Vol. 60: pp. 323-346.

La Porta, R., Lopez-deSilanes, F., \& Shleifer, A. 1998. "Law and Finance", Journal of Political Economy, Vol. 106, No. 6: pp. 11131155.

La Porta, R., Lopez-deSilanes, F., Shleifer, A., \& Vishny, R. W. 1997. "Legal Determinants of External", The Journal of Finance, Vol. LII, No. 3: pp. 1131-1150.

Leuz, C., Nandab, D., \& Wysockic, P. D. 2003. „Earnings Management and Investor Protection: An International Comparison.", Journal of Financial Economics, Vol. 69: pp. 505-527.
Lipe, R. 1986. "The Information Contained in the Components of Earnings", Journal of Accounting Research, Vol. 24 (Suplement): pp. 37-55.

Livnat, J., \& Zarowin, P. 1990. "The Incremental Information Content of Cash Flows Components", Journal of Accounting and Economics, Vol. 13: pp. 25 - 46.

McVay, S. E. 2006. "Earnings Management Using Classification Shifting: An Examination of Core Earnings and Special Items", The Accounting Review, Vol. 81, No. 3: pp. 501531.

Narsa, I. M. 2008. "Kemampuan Laba Fungsional dalam Menjelaskan Perilaku Aliran Kas", Majalah Ekonomi, Fakultas Ekonomi Universitas Airlangga, Tahun XVIII, No. 1: pp. $98-112$

Ohlson, J. A., \& Penman, S. H. 1992. „Disaggregated Accounting Data as Explanatory Variables for Returns", Journal of Accounting, Auditing and Finance, Vol. 7: pp. 553573

Ou, J. A. 1990. "The Information Content of Nonearnings Accounting Numbers as Earnings Predictors", Journal of Accounting Research, Vol. 28, No. 1 pp. 392-413.

Richadson, S. 2003. "Earnings Quality and Short Sellers”, Accounting Horizons, (Supplement): pp. 49 - 61.

Roychowdhury, S. 2006. "Earnings Management Through Real Activities Manipulation”, Journal of Accounting and Economics, Vol. 42: pp. 335 - 370.

Schipper, K., \& Vincent, L. 2003. "Earnings Quality". Accounting Horizons, (Supplement): pp. 97 - 110.

Scott, W. R. 2003. Financial Accounting Theory. Third Edition, Toronto: Prentice-Hall

Sloan, R. G. 1996. "Do Stock Prices Fully Reflect Information in Accruals and Cash Flows About Future Earnings?", The Accounting Review, Vol. 71, No. 3 (July): pp. 289 - 315.

Strong, N., \& Walker, M. 1993. "The Explanatory Power Of Earnings For Stock Return", The Accounting Review, Vol. 68: PP. 385 - 399

Swaminathan, S., \& Weintrop, J. 1991. "The Information Content Of Earnings, Revenues, And Expenses", Journal of Accounting Research Vol. 29, No. 2: pp. 418 - 427. 
Verbeek, M. 2004. A Guide to Modern Econometrics. 2nd Edition, Chichester, West Sussex, England: John Wiley \& Sons, Ltd.

Worthy, F. S. 1985. Manipulating Profits: How It's Done. Reading and Notes on Financial Accounting. Editor: Stephen A. Zeff dan Bala G. Dharan, Singapore: McGraw-Hill, pp. 651-658. 